\title{
Characterizing endogenous and exogenous peroxidase activity for bleaching of fluid whey and retentate
}

\author{
R. E. Campbell, ${ }^{*}$ P. D. Gerard, $†$ and M. A. Drake ${ }^{* 1}$ \\ *Department of Food, Bioprocessing and Nutrition Sciences, Southeast Dairy Foods Research Center, North Carolina State University, \\ Raleigh 27695 \\ †Department of Mathematical Sciences, Clemson University, Clemson, SC 29634
}

\begin{abstract}
The lactoperoxidase (LP) system may be used to achieve the desired bleaching of fluid whey with the addition of low concentrations $(<50 \mathrm{mg} / \mathrm{kg}$ ) of hydrogen peroxide. The addition of an exogenous peroxidase (EP) to whey may also be used to aid in whey bleaching when the LP system is not fully active. The objectives of this study were to monitor LP activity in previously refrigerated or frozen milk, fluid whey, and whey retentate (10\% solids) and to evaluate peroxidase activity in fluid whey and whey retentate $(10 \%$ solids), with and without additional EP $(2,1$, or 0.5 dairy bleaching units), over a range of $\mathrm{pH}(5.5-6.5)$ and temperatures $\left(4-60^{\circ} \mathrm{C}\right)$. Subsequent experiments were conducted to determine the relationship between enzyme activity and bleaching efficacy. Raw and pasteurized milk, fat-separated pasteurized whey, and whey retentate (10\% solids) were evaluated for LP activity following storage at 4 or $-20^{\circ} \mathrm{C}$, using an established colorimetric method. A response surface model was applied to evaluate both endogenous and EP activity at various temperatures and $\mathrm{pH}$ in freshly manufactured whey and retentate. Refrigerated or frozen storage at the parameters evaluated did not affect LP activity in milk, whey, or retentate. In fluid whey, with and without added EP, as $\mathrm{pH}$ decreased (to 5.5) and temperature increased (to $60^{\circ} \mathrm{C}$ ), peroxidase activity increased. Retentate with EP exhibited behavior similar to that of fluid whey: as $\mathrm{pH}$ decreased and temperature increased, activity increased. However, in retentate without EP, as $\mathrm{pH}$ increased and temperature increased, activity increased. Enzyme activity was negatively correlated to bleaching time (time for $>80 \%$ norbixin destruction) in fluid whey but a linear relationship was not evident in retentate. When fluid whey is bleached enzymatically, if $\mathrm{pH}$ is decreased and temperature is increased, the rate of reaction increases (e.g., bleaching occurs in less
\end{abstract}

Received July 7, 2013.

Accepted December 1, 2013.

${ }^{1}$ Corresponding author: maryanne_drake@ncsu.edu time). When bleaching in retentate, a higher $\mathrm{pH}(\mathrm{pH}$ 6.5 vs. $\mathrm{pH} 5.5)$ is desired for optimal bleaching by the LP system. Due to processing restraints, this may not be possible for all dairy producers to achieve and, thus, addition of EP could be beneficial to improve bleaching efficacy.

Key words: lactoperoxidase, whey, enzyme stability

\section{INTRODUCTION}

Lactoperoxidase (LP), a native enzyme found in milk, is often used to increase storage stability of raw milk (Seifu et al., 2005). Lactoperoxidase is a member of the peroxidase family and when its activators, thiocyanate $(\mathbf{S C N})$ and hydrogen peroxide $(\mathbf{H P})$, are present, hypothiocyanate, a potent antimicrobial, is produced (Reiter and Harnulv, 1982). In addition to milk preservation, the LP system can be used to bleach fluid whey (Bottomley et al., 1989; Campbell et al., 2012). Norbixin, a natural orange colored carotenoid, is often added to Cheddar cheese milk to impart desired color (Kang et al., 2010). A portion of norbixin is retained in the fluid whey. The strong oxidizing capacity of hypothiocyanate results in the destruction of carotenoid conjugation and subsequent color loss of norbixin in cheese whey.

Using the LP system to bleach whey can be highly variable, as levels of LP respectively vary depending on the lactation cycle of the cow, season, feeding regimen, and breed (Kussendrager and van Hooijdonk, 2000). Similar to LP, SCN concentration in milk and whey can vary widely due to feeding regimen (Seifu et al., 2005). The third component of the LP system, HP, is not normally detected in raw milk and is typically added exogenously. Hydrogen peroxide can be generated endogenously by bacteria, although amounts sufficient to activate the LP system may not be generated (Seifu et al., 2005). Depending on the milk, each component of the LP system could become the limiting factor to LP activity.

A commercial peroxidase is available to enhance fluid whey bleaching and its addition in small quantities 
helps achieve desired and consistent bleaching efficacy (Kang et al., 2010; Campbell and Drake, 2013; Szweda et al., 2013). This enzyme is derived from a mushroom, Marasmius scorodonius (Zorn et al., 2010). Contrary to the LP mechanism, the mechanism of this enzyme is not completely known; however, both of them require similar amounts of HP to activate their respective systems (Bottomley et al., 1989; Zorn et al., 2010). Since the original patent for this enzyme was filed in 2006, several papers have addressed the bleaching capacity of Marasmius scorodonius extracts on $\beta$-carotene in model systems (Scheibner et al., 2008; Pühse et al., 2009; Zelena et al., 2009). However, the activity and bleaching efficacy of this enzyme in conjunction with the natural LP system found in fluid whey or whey retentate have yet to be fully investigated. Fluid whey is often further processed into a value-added product, such as whey protein concentrate 34 or $80 \%$ or whey protein isolate (>90\% protein) that are commonly used in foods. Dried whey products are commonly used as ingredients in other foods. Consumers and food manufactures alike demand dried whey ingredients to be colorless with a bland flavor (Kang et al., 2010). The objectives of this study were to monitor LP activity in refrigerated or frozen storage in milk, fluid whey, and whey retentate (10\% solids) and to characterize peroxidase activity in fluid whey and whey retentate ( $10 \%$ solids), specifically activity with and without additional exogenous peroxidase $(\mathbf{E P})$, over a range of $\mathrm{pH}$ and temperatures by using a response surface model design.

\section{MATERIALS AND METHODS}

\section{Production of Whey and Retentate (80\% Protein)}

Raw clarified milk was obtained from the dairy at North Carolina State University (Raleigh). Milk was batch pasteurized at $63^{\circ} \mathrm{C}$ for $30 \mathrm{~min}$, which was followed immediately by cheese manufacture. Cheddar cheese whey was manufactured from vat-pasteurized whole bovine milk $(3.70 \pm 0.05 \%$ fat $)$ as described by Campbell et al. (2011). The whey was drained from the curds at $\mathrm{pH} 6.35$ and a sieve was used to remove any remaining particles. The whey was immediately processed with a hot bowl cream separator (model SI600E; Agrilac, Miami, FL) to reduce the fat content and then the whey was batch pasteurized at $63^{\circ} \mathrm{C}$ for $30 \mathrm{~min}$.

To produce retentate, the fat-separated pasteurized whey was transferred into a 102-L stainless vat (Fermenator; Blichmann Engineering, Lafayette, IN) equipped with a coil heater $(1.27 \mathrm{~cm}$ o.d.; PAC Stainless Ltd., Seattle, WA). The UF system (model Pellicon 2; Millipore Inc., Billerica, MA) was equipped with 5 polyethersulfone cartridge membrane filters (model
P2B010V05, $10 \mathrm{kDa}$ nominal separation cutoffs, 0.5$\mathrm{m}^{2}$ surface area; Millipore Inc.). Each sample was run through a peristaltic pump (model 77410-10; Millipore Inc.) and the UF assembly using silicone tubing (model 96440-73; Millipore Inc.) that was connected to the vat. Pumps, pump heads, and tubing were all obtained from Cole-Palmer (Vernon Hills, IL). This process continued until the retentate reached $80 \%$ protein (wt/vol) content confirmed by a Sprint rapid protein analyzer (CEM Corp., Matthews, NC). All treatments within each experiment were manufactured from the same lot of milk and the entire experiment was replicated in triplicate. For experiment 2, EP (MaxiBright; DSM Food Specialties Inc., Delft, the Netherlands) was added at a rate of 2,1 , or 0.5 dairy bleaching units $(\mathbf{D B L U}) / \mathrm{mL}$ to a portion of the wheys and retentates from each replication. Wheys and retentates were immediately $\mathrm{pH}$ adjusted using either lactic acid (85\%; VWR International LLC, West Chester, PA) or sodium hydroxide (1 N; VWR International LLC). A total of less than $0.5 \mathrm{~mL}$ of sodium hydroxide or lactic acid was used to adjust the $\mathrm{pH}$, such that the protein concentration was not affected. The pH-adjusted wheys and retentates were then placed in either a hot water bath or cold ice bath to equilibrate (30 min). Following $\mathrm{pH}$ adjustment and temperature equilibration, samples were immediately analyzed for peroxidase activity via spectrophotometry or norbixin content (bleaching) via HPLC.

\section{Experimental Overview}

This experiment consisted of 2 distinct parts. The objective of experiment 1 was to monitor the stability of LP in raw milk, pasteurized milk, pasteurized fat-separated Cheddar whey, and fluid Cheddar whey retentate ( $80 \%$ protein) during cold or frozen storage. The objective of experiment 2 was to monitor peroxidase activity in fluid Cheddar whey and fluid Cheddar whey retentate ( $80 \%$ protein) over a range of $\mathrm{pH}$ and temperatures. Experiments were subsequently conducted to confirm the relationship between enzyme activity and bleaching efficacy.

\section{Experiment 1}

Lactoperoxidase activity was monitored in raw whole milk, pasteurized whole milk, pasteurized fat-separated fluid Cheddar whey, and fluid Cheddar whey retentate during cold or frozen storage $\left(4\right.$ or $\left.-20^{\circ} \mathrm{C}\right)$ over time $(0,24,48$, and $72 \mathrm{~h})$ using an established colorimetric assay (Pruitt and Kamau, 1994). This experiment was replicated in triplicate. 


\section{Experiment 2}

Two factors were selected to optimize enzyme activity in fluid whey and retentate: $\mathrm{pH}(5.5-6.5)$ and temperature $\left(4-60^{\circ} \mathrm{C}\right)$. The evaluated ranges for $\mathrm{pH}$ and temperature were based on industrial dairy bleaching parameters (Table 1). Endogenous peroxidase (lactoperoxidase) as well as various levels of EP (MaxiBright; DSM Food Specialties Inc.); 2, 1, and 0.5 DBLU were evaluated. The factors $\mathrm{pH}$ and temperature and levels of each factor were arranged into a central composite response surface model design (Myers and Montgomery, 1995) with 2 center points. Because levels of $\mathrm{pH}$ were randomized within levels of temperature for each replication, a mixed-model approach to fitting was taken to accommodate this restriction on randomization. In addition to fixed effects, replication and replication $x$ temperature were random effects in the model due to linear and quadratic terms for temperature, $\mathrm{pH}$, and temperature $\times \mathrm{pH}$. The experiment was replicated 3 times using 3 different lots of milk; both fluid whey and retentate were made from the same lot of milk within each replication. The steps between the different levels of each factor were the same, with the midpoint value falling in the middle of the range of the 5 levels.

In subsequent experiments, 3 points were selected along $\mathrm{pH}$ and temperature curves for each matrix (fluid whey or retentate) and each enzyme level [2 DBLU of $\mathrm{EP}, 1 \mathrm{DBLU}$ of EP, $0.5 \mathrm{DBLU}$ of EP, and endogenous peroxidase (LP)] to further elucidate the relationship between peroxidase activity and bleaching time. Experiments were conducted in triplicate.

\section{Compositional Analysis}

Total solids of milk, liquid whey, and retentate were determined by air-oven drying (AOAC International, 2000; method number 990.20; 33.2.44). Fat was quantified using the Smart Trac rapid fat analyzer (CEM Corp.). Protein was determined using the Sprint rapid

Table 1. Response surface model design using 2 factors $(\mathrm{pH}$ and temperature)

\begin{tabular}{llc}
\hline Data point & $\mathrm{pH}$ & Temperature $\left({ }^{\circ} \mathrm{C}\right)$ \\
\hline 1 & 5.50 & 32 \\
2 & 5.65 & 12 \\
3 & 5.65 & 52 \\
4 & 6.00 & 4 \\
5 & 6.00 & 32 \\
6 & 6.00 & 32 \\
7 & 6.00 & 60 \\
8 & 6.35 & 12 \\
9 & 6.35 & 52 \\
10 & 6.50 & 32 \\
\hline
\end{tabular}

protein analyzer (CEM Corp.). All samples were measured in duplicate.

\section{Enzyme Activity Measurement (Experiments 1 and 2)}

Lactoperoxidase measurements and calculations on fluid milks, wheys, and retentates were performed according to the International Dairy Federation method (Pruitt and Kamau, 1994). The absorbance of the enzyme reaction mixture was measured and recorded 10 times per second for $2 \mathrm{~min}$ at $412 \mathrm{~nm}$ (Cary 300 UV-Vis; Agilent Technologies Inc., Cary, NC). Temperatures were controlled during measurement using a temperature control attachment to the spectrophotometer (TC125; Quantum Northwest Inc., Liberty Lake, WA). To prevent any condensation, compressed nitrogen continuously flowed through the sample cell. The derivative of the line fitted to the data using a fifth-order polynomial equation $\left(\mathrm{R}^{2}>0.97\right)$ was determined at time zero $(\mathrm{x}=0)$, which is presented as slope. The slope of the line may also be referred to as activity. The steeper the slope, the higher the enzyme activity and, thus, the faster the reaction proceeds.

\section{SCN Measurement (Experiment 1)}

Thiocyanate measurements of fluid milks, wheys, and retentates were performed according to the International Dairy Federation method (IDF, 1988). The concentration of SCN (Sigma-Aldrich, Milwaukee, WI) was determined by the use of external standard curves.

\section{Bleaching (Experiment 2)}

Liquid whey or retentate were first $\mathrm{pH}$ adjusted as previously described, as necessary. Fluid wheys or retentates were then placed in amber glass jars and allowed to equilibrate to proper temperature in either a hot water bath $\left(32\right.$ or $\left.60^{\circ} \mathrm{C}\right)$ or an ice bath $\left(4^{\circ} \mathrm{C}\right)$. Hydrogen peroxide (35\%, wt/vol; Nelson Jameson Inc., Marshfield, WI) was added to activate the peroxidase system $\left(4^{\circ} \mathrm{C}\right.$ : $10 \mathrm{mg} / \mathrm{kg} ; 32$ and $\left.60^{\circ} \mathrm{C}: 20 \mathrm{mg} / \mathrm{kg}\right)$. Aliquots of samples were removed at appropriate time points $(0,3,5,7,10,15,20,30,40$, and $50 \mathrm{~min}$, and 1 , $2,4,6$, and $24 \mathrm{~h}$ ) for norbixin extraction.

\section{Norbixin Extraction and Quantification (Experiment 2)}

Norbixin is the primary carotenoid in water-soluble annatto extracts and was extracted and measured to determine percent annatto destruction and bleaching efficacy (Kang et al., 2010). Norbixin was extracted and quantified using HPLC by the method described 
by Campbell et al. (2012). The extraction procedure and measurements were performed with premium full-spectrum F885 flat sheet filters covering all lights (Ergomart, Dallas, TX) to minimize norbixin isomerization and degradation (Mercadante, 2008). Norbixin concentration was calculated by TS and correction for dilution during the extraction.

\section{Statistical Analysis}

For experiment 1, a 2-way ANOVA comparing slopes was completed to compare LP and SCN in fluid milks, wheys, and retentates with storage (XLSTAT 2010; Addinsoft Inc., New York, NY). The main factors storage condition and storage time were analyzed along with their potential interaction effects. The Tukey honestly significant difference was used as a post hoc test.

For experiment 2, SAS (version 9.2; SAS Institute Inc., Cary, NC) was used to analyze the slope data. A mixed model (PROC MIXED) was used with replication and replication $\times$ temperature random effects in the model, in addition to fixed effects due to linear and quadratic terms for temperature and $\mathrm{pH}$ and the product of temperature and $\mathrm{pH}$. Predicted values from the response-fitted response surface model were plotted using PROC G3D. A mixed model (SAS Institute Inc.) was used to evaluate the bleaching experiment, which was conducted using a split-split plot design. Treatment was the whole-plot factor, matrix was the subplot factor, and enzyme was the sub-subplot factor. Treatment, matrix, enzyme, and all interactions were included in the model as fixed effects. Spearman's rank correlation coefficient (PROC CORR; SAS Institute Inc.) was used to determine the correlation between activity level and bleach time.

\section{RESULTS AND DISCUSSION}

\section{Experiment 1}

Composition of milk and wheys did not differ regarding the solids, protein, and fat contents. Milks averaged $12.2 \pm 0.2 \%$ solids, $3.39 \pm 0.01 \%$ protein, and $3.70 \pm 0.05 \%$ fat. Fluid wheys averaged $6.71 \pm 0.05 \%$ solids, $0.072 \pm 0.01 \%$ protein, and $0.04 \pm 0.01 \%$ fat. Retentates averaged $12.7 \pm 1.02 \%$ solids, $10.4 \pm 0.6 \%$ protein, and $0.95 \pm 0.09 \%$ fat. All measurements are reported on a wet-weight basis.

Lactoperoxidase activity values for all samples [raw milk, pasteurized milk, fat-separated pasteurized liquid whey, and fluid retentate $(80 \%$ protein)] did not decrease with storage time $(0,24,48$, or $72 \mathrm{~h})$ or storage conditions (refrigerated or frozen storage). Mullan et al. (1980) investigated the storage stability of LP in calf feed to reduce calf mortality and improve calf performance. Those authors reported that LP stability was highly variable and, in some cases, not stable in Cheddar cheese whey, losing as much as $50 \%$ activity over $3 \mathrm{~d}$ at $5^{\circ} \mathrm{C}$; however, this behavior was not consistent. In some experiments, enzyme levels were stable for $3 \mathrm{~d}$, consistent with results found in the current study. The rate of decrease in enzyme activity may be due to several factors: qualitative and quantitative nature of microbial flora, coagulant enzyme used, storage temperature of whey, and pH (Mullan et al., 1980). Peroxidase enzyme activity levels in whey protein concentrates (11.29\% solids and $9.32 \%$ protein) were stable for at least 4 mo when stored at $-30^{\circ} \mathrm{C}$ (Mullan et al., 1980); once again, this is in agreement with the present study.

Milk pasteurization did not affect LP activity (raw milk slope $=0.214$; pasteurized milk slope $=0.213)$. The present study used low-temperature, long-time pasteurization and, thus, it is expected from previous studies that this pasteurization step would not affect LP activity in milk. The effect of heat treatment on bovine LP activity has been widely studied. Marín et al. (2003) found that when mild heat treatments were applied $\left(68^{\circ} \mathrm{C}\right.$ for $15 \mathrm{~min}$ or $72^{\circ} \mathrm{C}$ for $\left.2 \mathrm{~min}\right)$, more than $90 \%$ of the LP activity was retained. Lactoperoxidase is more resistant to long treatments at low temperatures than short treatments at high temperatures (Marín et al., 2003).

Fluid whey exhibited a higher LP activity slope than fluid milks, averaging 1.59 and 0.214 , respectively (Figure 1). Previous studies have reported higher activity in wheys than milk (Seifu et al., 2005; Campbell et al., 2012). Retentate had the highest LP activity slope of all samples tested $(P<0.05)$, with slopes averaging 9.08 (results not shown). It is expected that retentates would have higher activity values, as the LP is being concentrated during the UF process.

\section{Experiment 2}

Composition did not different among replications. Fluid whey averaged $6.71 \pm 0.05 \%$ solids, $0.071 \pm$ $0.01 \%$ protein, and $0.03 \pm 0.01 \%$ fat. Retentates averaged $10.6 \pm 0.45 \%$ solids, $8.80 \pm 0.20 \%$ protein, and $0.67 \pm 0.05 \%$ fat. All measurements are reported on a wet-weight basis.

Temperature, regardless of matrix, influenced LP activity. In fluid whey with and without added exogenous enzyme, and in retentate with added exogenous enzyme at the various levels tested $(2,1$, or 0.5 DBLU), the temperature effect was more pronounced than the $\mathrm{pH}$ effect (Figures 2, 3, 4, 5, 6, 7, and 8). In milk and diluted whey, lactoperoxidase was optimally active at approximately $50^{\circ} \mathrm{C}$ (Ludikhuyze et al., 2001). Peroxi- 


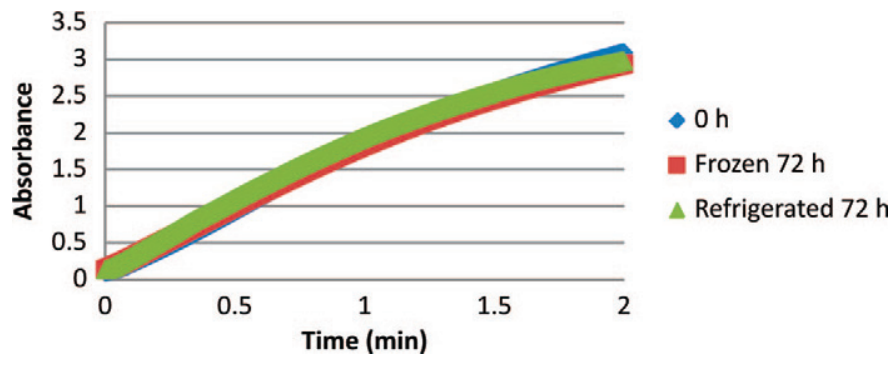

Figure 1. Lactoperoxidase activity in fluid whey over $72 \mathrm{~h}$ of refrigerated or frozen storage using the International Dairy Federation method (Pruitt and Kamau, 1994) to determine activity. Color version available in the online PDF.

dase activity in retentate, without the addition of EP, was more thermostable at more neutral pH (Figure 9). This behavior is very similar to horseradish peroxidase, which also exhibits more thermostability at neutral $\mathrm{pH}$ (Lemos et al., 2000). Horseradish peroxidase is widely studied, arguably the most studied peroxidase enzyme, with numerous studies agreeing that optimum thermostability occurs at $\mathrm{pH} 7$ (Lemos et al., 2000). The effect of $\mathrm{pH}$ and the medium all influence the thermal stability of the enzyme being studied. Both bovine LP and EP are rather thermostable and highly resistant to pressure (Ludikhuyze et al., 2001; Pühse et al., 2009). Exogenous peroxidase (MaxiBright) has an optimal activity around 55 to $60^{\circ} \mathrm{C}$ (Pühse et al., 2009). Above $65^{\circ} \mathrm{C}$, the enzyme begins to have conformational changes and above $78^{\circ} \mathrm{C}$, enzyme activity decreases abruptly (Pühse et al., 2009). Lactoperoxidase, similar to EP, experiences a sharp decline in activity around 78 to $80^{\circ} \mathrm{C}$ (de Wit and van Hooydonk, 1996; Seifu et al., 2005). The 3 main processes considered to be involved in thermal inactivation of peroxidases are (1) dissociation of the prosthetic (heme) group from the active enzyme system, (2) conformation change in the apoenzyme, and (3) modification or degradation of the prosthetic group (Lemos et al., 2000). Knowing the

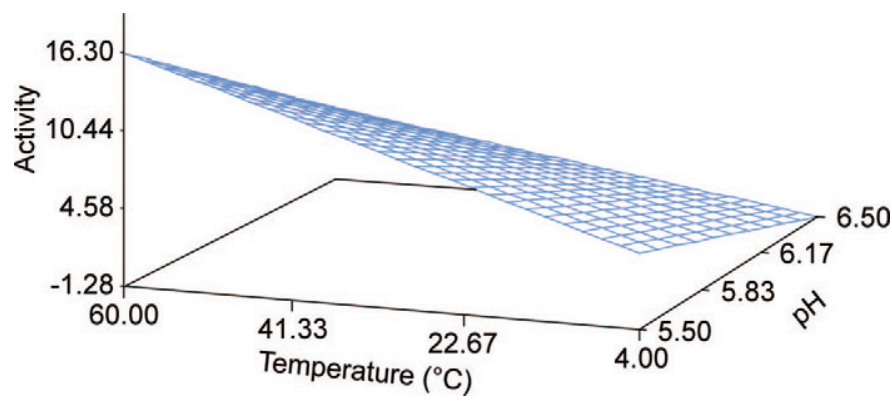

Figure 2. Three-dimensional model displaying the effects of temperature and $\mathrm{pH}$ of fluid whey with added exogenous enzyme (2 dairy bleaching units) on enzyme activity. Color version available in the online PDF.

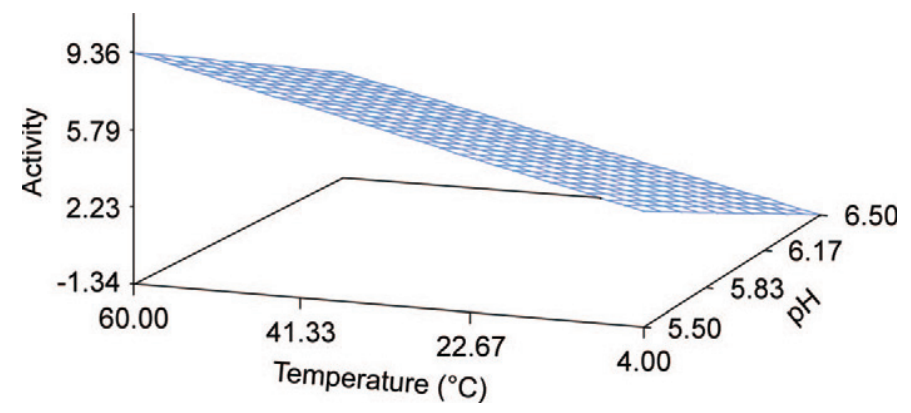

Figure 3. Three-dimensional model displaying the effects of temperature and $\mathrm{pH}$ of fluid whey with added exogenous enzyme (1 dairy bleaching unit) on enzyme activity. Color version available in the online PDF.

optimal activity temperature for both of these enzymes will help to ensure that optimal bleaching occurs during whey processing.

The pH optimum for the LP enzyme is highly dependent upon the particular electron donor (Pruitt et al., 1983). The most obvious choice of electron donor in the case of LP in bovine milk is SCN, as it is naturally present in milk. Previous studies have shown that myeloperoxidase (a peroxidase enzyme found in human mucus) and LP are similar in mechanism, with both enzymes able to carry out the peroxidation of SCN over a broad pH range (Wever et al., 1982). The kinetics of the peroxidation catalyzed by LP are complex, with HP and SCN acting not only as substrates but also as competitive inhibitors with respect to each other (Wever et al., 1982). A study conducted by Wever et al. (1982) demonstrated that the position of the $\mathrm{pH}$ optima was a linear function of the logarithm of the [SCN]:[HP] ratio. As the ratio increased, so did the $\mathrm{pH}$ optima. In a study conducted not long after Wever et al. (1982), Pruitt et al. (1983) confirmed that the LP system was highly dependent on both the relative and absolute values of $\mathrm{SCN}$ and $\mathrm{HP}$ concentrations. At varying

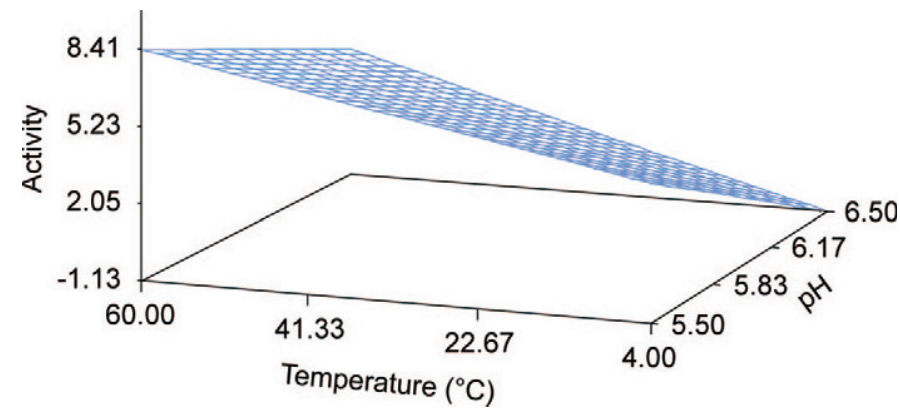

Figure 4. Three-dimensional model displaying the effects of temperature and $\mathrm{pH}$ of fluid whey with added exogenous enzyme $(0.5$ dairy bleaching units) on enzyme activity. Color version available in the online PDF. 


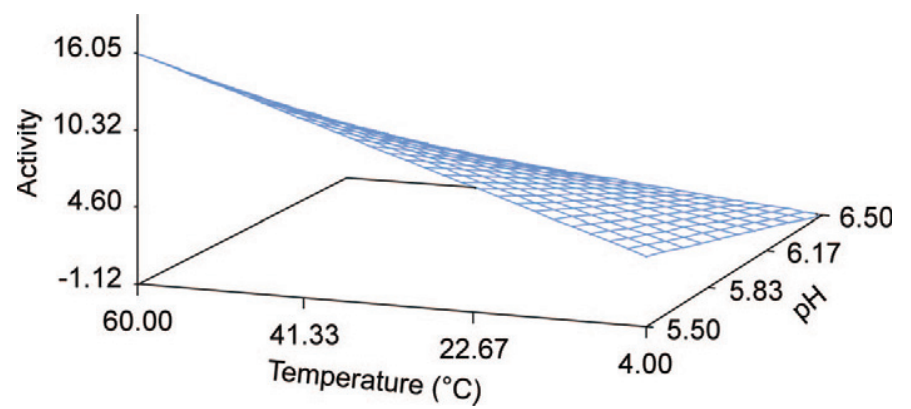

Figure 5. Three-dimensional model displaying the effects of temperature and $\mathrm{pH}$ of fluid whey without added exogenous enzyme (lactoperoxidase only) on enzyme activity. Color version available in the online PDF.

equimolar concentrations of SCN and HP, Pruitt et al. (1983) demonstrated that as SCN and HP decreased, the $\mathrm{pH}$ optima increased. For example, when SCN and $\mathrm{HP}$ were at equimolar concentrations in the range of 0.5 to $2 \mathrm{mM}$, the $\mathrm{pH}$ optimum was near 6.0 . When SCN was in large excess $(10 \mathrm{mM})$, the $\mathrm{pH}$ optimum was near 6.7. Dependence of $\mathrm{pH}$ was similar for both the human saliva system and for the bovine LP system, with the optimum in the $\mathrm{pH}$ range of 6.5 to 7 in $\mathrm{PBS}$ solution (Pruitt et al., 1983).

The $\mathrm{pH}$ optima of bovine LP in fluid whey and retentate were very different from each other. In fluid whey, the $\mathrm{pH}$ optimum was much lower than in retentate (Figures 5 and 9). Exact reasons for this are unknown; however, from previous literature, it can be speculated that SCN concentration and HP concentration heavily influence the $\mathrm{pH}$ maxima. As fluid whey is ultrafiltered and diafiltered to retentate, permeate consisting of lactose, minerals, and other small particles (less than $10 \mathrm{KDa}$ ) is removed. Thiocyanate is among one of these constituents that is removed, thus decreasing the $[\mathrm{SCN}]:[\mathrm{HP}]$ ratio and undoubtedly causing the $\mathrm{pH}$ optimum to shift. Thiocyanate levels in fluid whey

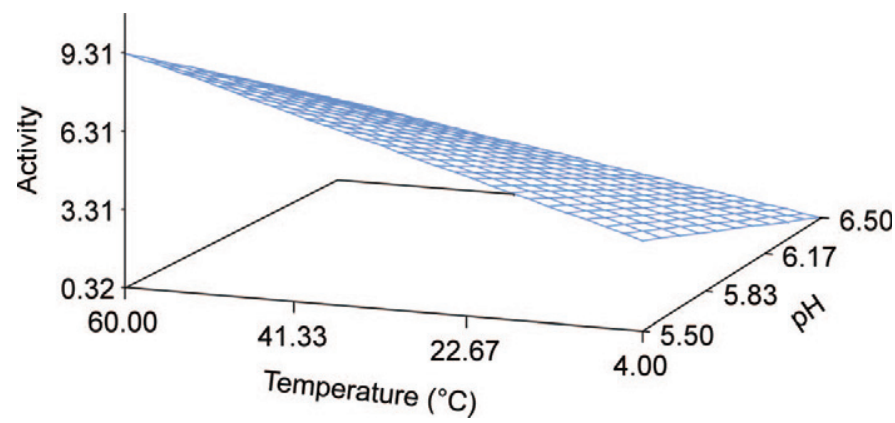

Figure 6. Three-dimensional model displaying the effects of temperature and $\mathrm{pH}$ of retentate with added exogenous enzyme (2 dairy bleaching units) on enzyme activity. Color version available in the online PDF.

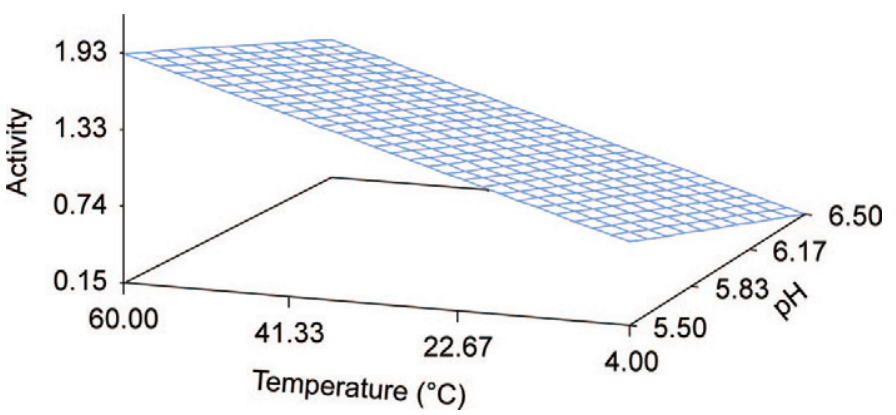

Figure 7. Three-dimensional model displaying the effects of temperature and $\mathrm{pH}$ of retentate with added exogenous enzyme (1 dairy bleaching unit) on enzyme activity. Color version available in the online PDF.

averaged $4.7 \mathrm{mg} / \mathrm{kg}$, whereas retentate levels averaged $3.9 \mathrm{mg} / \mathrm{kg}(P<0.05)$. When exogenous enzyme was added $(2,1$, or 0.5 DBLU), the $\mathrm{pH}$ optimums of fluid whey and fluid retentate were very similar (Figures 2, $3,4,6,7$, and 8). Activity values in retentate without the addition of exogenous enzyme were opposite with regard to $\mathrm{pH}$ : as $\mathrm{pH}$ increased, activity increased (Figure 9). An increase in temperature also increased enzyme activity; however, $\mathrm{pH}$ had a much greater effect on enzyme activity than temperature (Figure 9).

Activity is a quick, easy, and inexpensive way to measure enzymatic activity; however, practically, it is important to understand if and how activity relates to norbixin destruction (bleaching based on time to $>80 \%$ norbixin destruction). Three points were selected along each activity curve to further elucidate the relationship between bleaching, enzyme activity, and bleach time (Figure 10).

Across all treatments, retentate or liquid whey and various levels of EP, activity increased with increasing temperature. Norbixin analysis demonstrated that the speed of norbixin destruction (bleaching based on time to $>80 \%$ norbixin destruction) also increased with

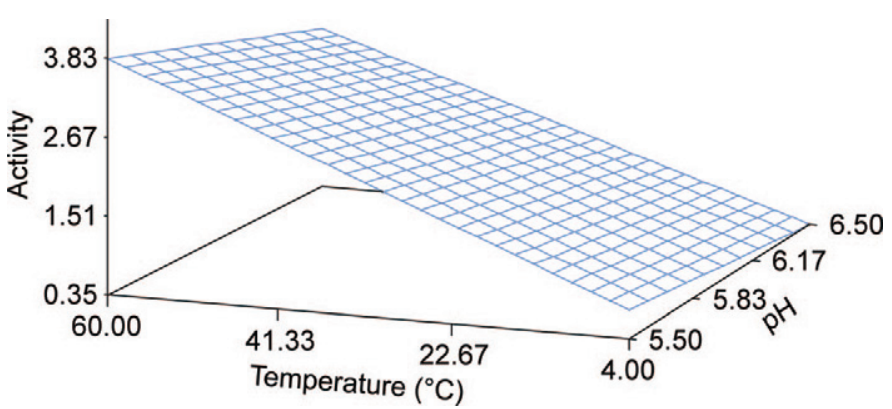

Figure 8. Three-dimensional model displaying the effects of temperature and $\mathrm{pH}$ of retentate with added exogenous enzyme $(0.5$ dairy bleaching units) on enzyme activity. Color version available in the online PDF. 


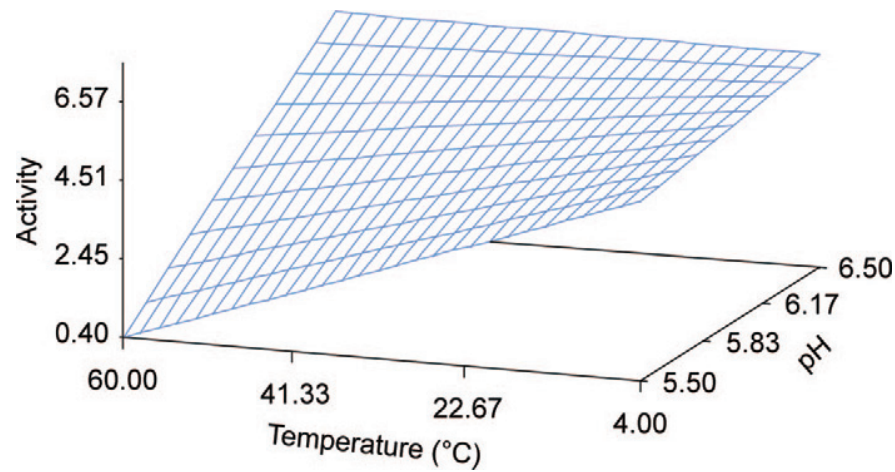

Figure 9. Three-dimensional model displaying the effects of temperature and $\mathrm{pH}$ of retentate without added exogenous enzyme (lactoperoxidase only) on enzyme activity. Color version available in the online PDF.

increasing temperature. In liquid whey, the speed of bleaching increased with the addition of EP at all temperatures $\left(4,32\right.$, and $60^{\circ} \mathrm{C}$; Figure 10). In retentate, EP increased the speed of bleaching only at 4 and $32^{\circ} \mathrm{C}$ and these effects were only observed at the higher levels of added EP ( 1 and 2 DBLU). Increased activity did not reflect increased bleaching with the addition of EP in retentate. In fluid whey, activity and bleaching time were negatively correlated $(\mathrm{r}=-0.73 ; P<0.05)$; thus, as activity increased, the time needed to bleach $(>80 \%$ norbixin destruction) decreased. In retentate, no correlation was found between activity and bleaching ( $\mathrm{r}$
$=-0.23)$. This result suggests that the relationship between enzymatic activity and bleaching is not linear in retentate. However, retentate, even without the addition of EP, bleached much faster than fluid whey (for example, at $32^{\circ} \mathrm{C},>80 \%$ of norbixin was destroyed in 37 min in fluid whey versus $7 \mathrm{~min}$ in retentate) and, thus, it may not be possible to accurately measure bleaching in such a short time frame $(<3 \mathrm{~min})$ and a correlation may exist, but due to equipment limitations, it may not be possible to detect.

\section{CONCLUSIONS}

Lactoperoxidase activity following $0,24,48$, or $72 \mathrm{~h}$ of storage at 4 or $-20^{\circ} \mathrm{C}$, regardless of matrix (milk, whey, or retentate) did not decrease. In fluid whey, regardless of added exogenous enzyme, as $\mathrm{pH}$ decreased (from 6.5 to 5.5) and temperature increased (from 4 to $60^{\circ} \mathrm{C}$ ), enzyme activity increased. In fluid retentate, added exogenous enzyme made a significant difference in the optimal parameters for enzyme activity. Lactoperoxidase activity in retentate without additional enzyme increased as pH (from 5.5 to 6.5 ) and temperature increased (from 4 to $60^{\circ} \mathrm{C}$ ). Enzyme activity behavior in retentate with the addition of exogenous enzyme demonstrated that as $\mathrm{pH}$ decreased (from 6.5 to 5.5) and temperature increased (from 4 to $60^{\circ} \mathrm{C}$ ), so did enzyme activity. Enzymatic bleaching is complex and an increase in peroxidase activity did not necessar-

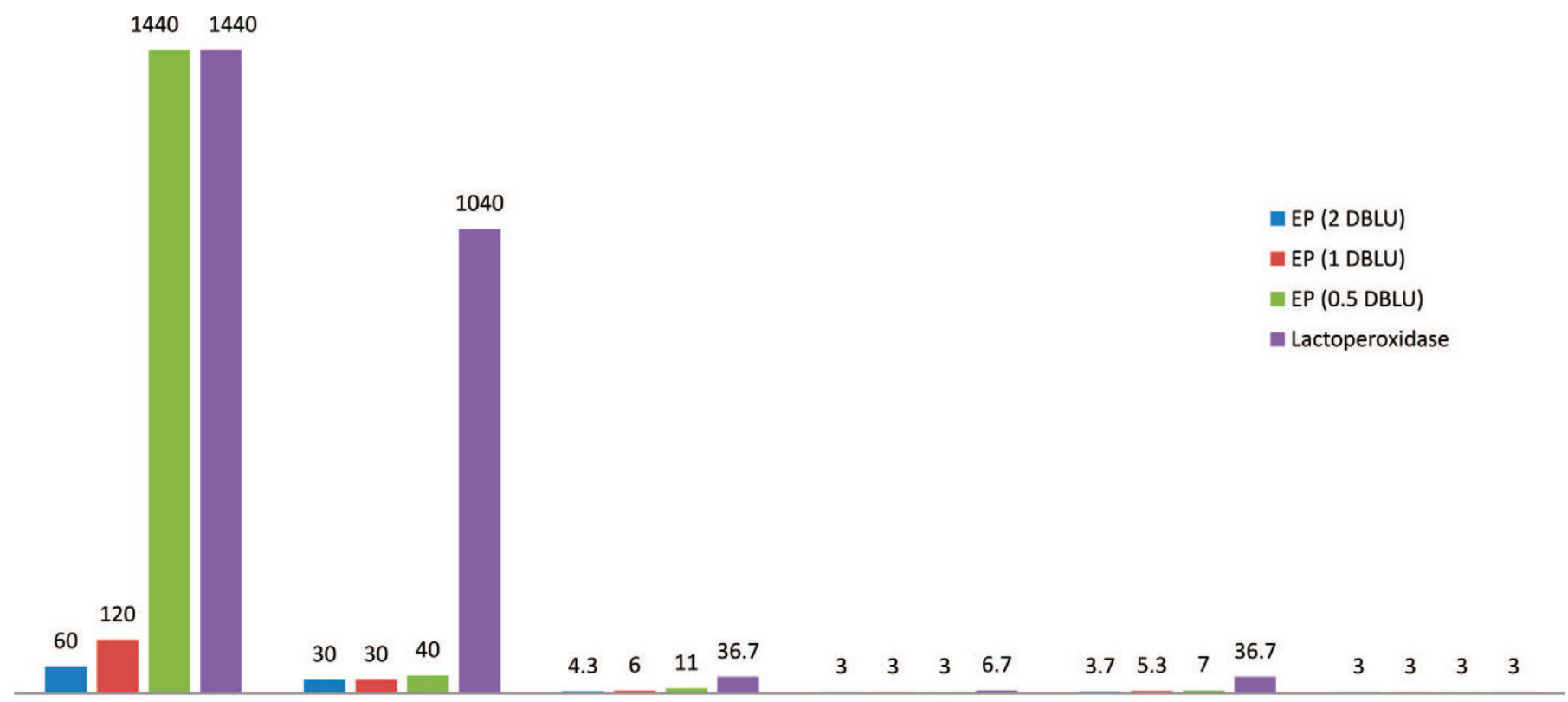

Liquid Whey $4^{\circ} \mathrm{C}$, pH 6.5 Retentate $4^{\circ} \mathrm{C}$, pH 6.5 Liquid Whey $32^{\circ} \mathrm{C}$, pH 6.0 Retentate $32^{\circ} \mathrm{C}$, pH 6.0 Liquid Whey $60^{\circ} \mathrm{C}$, pH $5.5 \quad$ Retentate $60^{\circ} \mathrm{C}$, pH 5.5

Figure 10. Amount of time in minutes (y-axis) to bleach $>80 \%$ norbixin using lactoperoxidase with or without added exogenous peroxidase (EP) in fluid whey or retentate ( $10 \%$ solids and $80 \%$ protein) at various temperatures and $\mathrm{pH}$. DBLU $=$ dairy bleaching units. Color version available in the online PDF. 
ily correlate to an increase in bleaching. Knowing the proper parameters can help dairy processers further optimize enzymatic bleaching in fluid whey and retentate.

\section{ACKNOWLEDGMENTS}

Funding was provided in part by the Dairy Research Institute [DRI; formerly Dairy Management Inc. (DMI); Rosemont, IL] and DSM Food Specialties Inc. (Delft, the Netherlands). The advice and assistance of Eric Bastian (Glanbia Foods Inc., Twin Falls, ID) is gratefully acknowledged. The use of trade names does not imply endorsement or lack of endorsement by those not mentioned.

\section{REFERENCES}

AOAC International. 2000. Official Methods of Analysis. 17th ed. AOAC International, Gaithersburg, MD.

Bottomley, R. C., R. D. Colvin, and M. Van Blanton, inventors. 1989. Decolorising of whey and whey products derived from whey. Express Foods Group Ltd, (Middlesex, GB2), assignee. US Pat. No. $4,888,184$.

Campbell, R. E., and M. A. Drake. 2013. Cold enzymatic bleaching of fluid whey. J. Dairy Sci. 96:7404-7413.

Campbell, R. E., E. J. Kang, E. Bastian, and M. A. Drake. 2012. The use of lactoperoxidase for the bleaching of fluid whey. J. Dairy Sci. 95:2882-2890.

Campbell, R. E., R. E. Miracle, and M. A. Drake. 2011. The impact of starter culture and annatto on the flavor and functionality of whey protein concentrate. J. Dairy Sci. 94:1185-1193.

de Wit, J. N., and A. C. M. van Hooydonk. 1996. Structure, functions, and applications of lactoperoxidase in natural antimicrobial systems. Neth. Milk Dairy J. 50:227-244.

IDF. 1988. Code of practice for the preservation of raw milk by the lactoperoxidase system. Bull. No. 234. International Dairy Federation, Brussels, Belgium.

Kang, E. J., R. E. Campbell, E. Bastian, and M. A. Drake. 2010. Invited review: Annatto and bleaching in dairy foods. J. Dairy Sci. 93:3891-3901.

Kussendrager, K. D., and A. C. M. van Hooijdonk. 2000. Lactoperoxidase: Physico-chemical properties, occurrence, mechanism of action, and applications. Br. J. Nutr. 84:S19-S25.

Lemos, M. A., J. C. Oliveira, and J. A. Saraiva. 2000. Influence of $\mathrm{pH}$ on the thermal inactivation kinetics of horseradish peroxidase in aqueous solution. Lebenson. Wiss. Technol. 33:362-368.
Ludikhuyze, L. R., W. L. Claeys, and M. E. Hendrickx. 2001. Effect of temperature and/or pressure on lactoperoxidase activity in bovine milk and acid whey. J. Dairy Res. 68:625-637.

Marín, E., L. Sánchez, M. D. Pérez, P. Puyol, and M. Calvo. 2003. Effect of heat treatment on bovine lactoperoxidase activity in skim milk: Kinetic and thermodynamic analysis. J. Food Sci. 68:89-93.

Mercadante, A. Z. 2008. Food colorants: Chemical and functional properties. Pages 447-478 in Analysis of carotenoids. C. Socaciu, ed. CRC Press, Boca Raton, FL.

Mullan, W. M. A., A. Waterhouse, G. Davies, and V. N. Wade. 1980. The production and storage stability of lactoperoxidase containing feeding materials for calf rearing experiments. Dairy Ind. Int. 45:15-17.

Myers, R. H., and D. C. Montgomery. 1995. Response Surface Methodology. John Wiley \& Sons Inc., New York, NY.

Pruitt, K. M., and D. N. Kamau. 1994. Quantitative analysis of bovine lactoperoxidase system components and the effects of the activated system on bacterial growth and survival. Pages $73-87$ in Indigenous Antimicrobial Agents of Milk-Recent Developments. International Dairy Federation, Brussels, Belgium.

Pruitt, K. M., B. Mansson-Rahemtulla, and J. Tenovuo. 1983. Detection of the hypothiocyanite $\left(\mathrm{OSCN}^{-}\right)$ion in human parotid saliva and the effect of $\mathrm{pH}$ on $\mathrm{OSCN}^{-}$generation in the salivary peroxidase antimicrobial system. Arch. Oral Biol. 28:517-525.

Pühse, M., R. T. Szweda, Y. Ma, C. Jeworrek, R. Winter, and H. Zorn. 2009. Marasmius scorodonius extracellular dimeric peroxidase - Exploring its temperature and pressure stability. Biochim. Biophys. Acta 1794:1091-1098.

Reiter, B., and B. G. Harnulv. 1982. Preservation of refrigerated and uncooled milk by its natural lactoperoxidase system. Dairy Ind. Int. 47:13-19.

Scheibner, M., B. Hülsdau, K. Zelena, M. Nimtz, L. de Boer, R. G. Berger, and H. Zorn. 2008. Novel peroxidases of Marasmius scorodonius degrade $\beta$-carotene. Appl. Microbiol. Biotechnol. 77:12411250 .

Seifu, E., E. M. Buys, and E. F. Donkin. 2005. Significance of the lactoperoxidase system in the dairy industry and its potential applications: A review. Trends Food Sci. Technol. 16:137-154.

Szweda, R. T., K. Schmidt, and H. Zorn. 2013. Bleaching of colored whey and milk by a multiple-enzyme system. Eur. Food Res. Technol. 237:377-384

Wever, R., W. M. Kast, J. H. Kasinoedin, and R. Boelens. 1982. The peroxidation of thiocyanate catalysed by myeloperoxidase and lactoperoxidase. Biochim. Biophys. Acta 709:212-219.

Zelena, K., B. Hardebusch, B. Hülsdau, R. G. Berger, and H. Zorn. 2009. Generation of norisoprenoid flavors from carotenoids by fungal peroxidases. J. Agric. Food Chem. 57:9951-9955.

Zorn, H., and M. Scheibner, B. Hülsdau, R. G. Berger, L. De Boer, and R. B. Meima. 2010. Novel enzymes for use in enzymatic bleaching of food products. Nixon \& Vanderhye PC, assignee. US Pat. No. 20100055237A1. 